\title{
Development of Coastal Protection Structure in Karawang Coastal Area of Indonesia
}

\author{
Eny Budi Sri Haryani ${ }^{1 *}$, Roberto Pasaribu ${ }^{2}$, Liliek Soeprijadi ${ }^{2}$, Anthon Anthonny Djari ${ }^{2}$, Chrisoetanto P. Pattirane ${ }^{2}$ \\ ${ }^{1}$ Study Program of Marine Engineering, Institute of Transportation and Logistics Trisakti, Jakarta, Indonesia \\ ${ }^{2}$ Marine and Fisheries Polytechnic Karawang, Ministry of Marine Affairs and Fisheries, Indonesia \\ *Corresponding Author
}

\begin{abstract}
This research is a case study on the coast of Karawang Regency, West Java Province, which is part of the North Coast of Java. In the coastal area of Karawang, it was previously planned to build a port, but it was canceled and shifted to another regency. How is the condition of the Karawang coast? Has it undergone physical changes and is it risky if a port is built, and do it need some coastal protection strutures to protect it from damage? What kind of coastal structures are suitable to protect the coast of Karawang? These question are at the same time a problem that will be raised in this study. The objectives of this research are: (1) to plan a coastal protection structure for the coast of Karawang; (2) to determine the type and structure of coastal protection structures that are suitable for the Karawang coast. Research data in the form of primary and secondary data, with primary data covering topography, bathymetry, tides, currents, obtained by validation through Ground Check Points (GCP), and secondary data covering wind, and socioeconomic. Analysis of the data through simulation and determination of the selected coastal structures, with the result that the appropriate coastal protection structures are breakwaters and groynes, because they can reduce the overflow of waves that occur, so that the coast is protected from the onslaught of damaging waves.
\end{abstract}

Keywords: Karawang coast, physical changes of the coast, coastal protection structures, breakwater, groyne.

\section{INTRODUCTION}

$\mathrm{C}$ oastal area of Karawang, is part of the North Coast of Java Island and Karawang Regency is an area of West Java Province of Indonesia. In 2015, on the coast of Karawang Regency, especially the coast of Cilamaya, it was planned to build a public sea port, but it was cancelled dan moved to another regency. The market share of the Cilamaya port is planned to be 60 percent of the industrial area in Cikarang and Bekasi. This is because the initial scheme for the port project plan was to anticipate industrial growth in the eastern Jakarta area and the over-capacity of Tanjung Priok Port, in Jakarta of Indonesia [15].

There are many reasons for the cancellation rumors, considering that the port is a strategic infrastructure, so that various speculations have appeared in various reports in the mass media, ranging from political, business and physical conditions of the beach. Among other things, the Cilamaya coast was considered unsatisfactory for a port to be built and a beach with a 10-kilometers-wide shipping lane corridor was sought on the North Coast of Java. While previously, almost 5 years, a feasibility study has been carried out and has been declared feasible to be built, so the feasibility study becomes wasteful and useless [15].

However, if you look at the biophysical condition of the Karawang coast as a whole, is it really not suitable for the port area? Determining a suitable coastal area for a port to be built is not easy, it requires rigorous technical requirements and must be calculated correctly with the field conditions [10] [21]. Previously in general, the coastal area in Karawang is a good coast and beautiful and Karawang also has a coastal area where the population is productive, working in the field of fisheries, both capture and aquaculture. Besides, it is a tourist area for local residents because of the charm of its beautiful beaches [11].

Because many of the residents work as fishermen, Karawang also has several fishing business centers, which are usually for fish landing activities or traditional fishing ports, which are not only used for landing fish in the sea, but also for selling fish catch transactions. In this area, it is usually just a traditional infrastructure, for anchoring fishing boats, where in Karawang every productive coastal village in a sub-district has this traditional facility [7]. With these conditions, Karawang does not yet have adequate fishing port infrastructure, even though the fishery potential is quite good. The fishing port closest to Karawang is the Cirebon fishing port, which is a different regency and is quite far away. Moreover, public sea port facilities do not yet exist in Karawang, the closest sea port to Karawang is the Tanjung Priok international sea port, and unfortunately the 2015 plan to build a public port in Cilamaya was canceled and shifted to other regency [7].

With the information as described above, the question is, what is the actual physical condition of the Karawang coast? Has it been damaged and it is not possible to build adequate infrastructure? Or, as coastal areas on earth, are always threatened by changes in their physical conditions, because of activities at sea? As mentioned in workshop paper of [3], not published yet, that although previously the coast of Karawang was good and also productive, it cannot be denied, in some areas it has been damaged due to activities at sea, causing ocean waves and sediment transport, which damage the coast of Karawang, resulting in physical changes, namely abrasion and sedimentation, including the retreat of the 
coastline which disrupts activities in that place and is dangerous if not handled properly. Therefore, it requires special handling, for example by making coastal protection structures (hard solution), such as groynes, jetties, revetments, seawalls, or breakwaters [21] [28].

A coastal area is a land and its waters where the area is still influenced by both land and marine activities [21] [28]. It is alleged that Karawang coastal area has suffered a lot of physical damage due to activities at sea, so a coastal protection structure is needed to overcome the damage. Therefore, it is necessary to consider various factors that cause coastal damage, and how they affect the environment. Coastal areas have complex water dynamics. The main processes that often occur include circulation of water masses, mixing (especially between two different water masses), abrasion, sedimentation and upwelling. This process occurs because of the interaction between various components such as land, sea, and atmosphere [13].

Various factors that cause coastal damage must be carefully researched and considered, so that the solutions taken are truly effective in tackling coastal damage, especially at the research location in Karawang. The solution, of course, does not only have to make coastal protection structures as fisical materials, which are hard solutions (structures), but also can be used soft solutions (non-structures) as coastal protection is carried out naturally with the existence of mangrove trees, coral reefs and other types [9]. Therefore, a proper study is needed to determine the best solution to protect the coast from physical damage. As is known from the research of [16] that most of the mangroves in Karawang have also been degraded. Likewise, in most of Indonesia's coastal areas, mangroves and coral reefs have suffered a lot of damage which interferes with the development of sustainable fisheries [4]. In this case, this research is limited to hard solutions, namely solutions by developing coastal protection structures. So that the design of the chosen coastal protection structures must be in accordance with the problems in the coastal area of Karawang. Because the selection of the right design will help prevent and minimize greater coastal damage due to waves and other activities [14].

To determine the type of coastal protection structure as a way to overcome coastal damage on the coast of Karawang Regency, it can be done by collecting, processing and analyzing location data which has been severely damaged, in which the bathymetry conditions, coastline, currents, waves and tides, which have been validated by conducting Ground Check Point (GCP) along the coast of Karawang Regency. Basically, wave conditions and topography can determine the type of coastal structures that are suitable to protect the coast from damage [9].

Prediction of shoreline change can be done using special software, such as GENESIS (Generalized Model for Simulating Shoreline Change) [6] [25]. This prediction is intended to determine changes in the coastline that occur within a certain period of time with existing conditions, so that it can be seen the changes in the coastline that will occur, then from these changes can be made the selection of an alternative effective coastal protection structures for handling problems caused by changes in the coastline. In selecting the alternative structure, the structure chosen is the one that has the most effective influence in dealing with the problem of changing shorelines.

From the research whose results have been presented in the workshop paper of [3], which have not been published yet, it is known that 6 (six) locations were seriously damaged by abrasion and sedimentation on the coast of Karawang, namely in Muara Cilamaya Lama Village, Sukajaya Village, Pusakajaya Utara Village, Sedari Village, Tambaksari Village, and Tanjungpakis Village. Predictions of the rate of abrasion and sedimentation are also well known, but the planning and model of coastal structures that can be used requires more in-depth research so that the solutions to be implemented are targeted and effective.

Several studies related to coastal protection structure for the prevention of abrasion and sedimentation have been carried out in Indonesia, but have never been carried out on the coast of Karawang Regency. [17] conducted an analysis of shoreline change and land cover between Way Penet and Way Sekampung, East Lampung Regency. [25] conducted an analysis of coastal protection structures in the Mundu area, Balongan, Indramayu Regency. [26] conducted an analysis of natural boundary conditions on abrasion on the coast of Lampung.

Then, [8] conducted an analysis of the groyne design to overcome the erosion of the northern coastal area of Baguala Bay, Ambon. [24] conducted a research on the change model of the east coast line of Tarakan, East Kalimantan. [6] conducted an analysis of shoreline changes for 10 years using CEDAS (Coastal Engineering Design and Analysis System) in Awur Bay Waters, Jepara Regency, in the scenario of adding coastal protective structure. [23] conducted a spatial analysis of shoreline changes on the coast of Subang Regency, West Java. [1] is planning an alternative coastal protection structure for Namrole Beach in Buru Selatan-Maluku Regency. [19] conducted an analysis of the dynamics of shoreline changes in the waters of Banten Bay and its surroundings. [2] conducted modeling and analysis of shoreline changes in Situbondo Regency, East Java.

Therefore, this research on the coast of Karawang Regency is urgent, because no previous research has been conducted, or there are no research results that recommend certain types of coastal buildings that are appropriate for the Karawang coast. Meanwhile, the coast of Karawang is a potential area for marine and fisheries, tourism, community settlements, and potential as an area to build a public sea port. Determining the right type of special beach building for the Karawang coast will also help facilitate decision making, if in the future strategic infrastructure will be built, including for example a public sea port will be built. 
From the description of the background, the main problems of this research are formulated: (1) how to plan a coastal protection structures for the Karawang coast? (2) how to determine the appropriate type and structure of coastal protection for the coast of Karawang? Meanwhile, the objectives of this research are: (1) planning for coastal protection structures for the coast of Karawang; (2) determine the type and structure of coastal protection structures that are suitable for the Karawang coast.

While the benefits of this research, apart from knowing the benefits of coastal protection buildings in preventing beach damage on the coast of Karawang, it can also help local governments develop plans for developing coastal areas of Karawang Regency. So that from the results of this study it is very useful to help formulate appropriate policies for the Karawang coast, including if a public sea port is to be built later, it is known what kind of coastal structures design is appropriate to protect the Karawang coast from the threat of physical damage, therefore this research was conducted .

\section{MATERIALS AND METHODS}

\section{A. Area and Time Frame of The Study}

The research was conducted in coast of Karawang, Indonesia, in locations where abrasion and sedimentation have occurred [3], namely at: (1) Muara Cilamaya Lama Village coast; (2) Sukajaya Village coast; (3) Pusakajaya Utara Village coast; (5) Sedari Village coast; (6) Tambaksari Village coast; (7) Tanjungpakis Village coast, with the point of observation location can be seen in Fig. 1. While the time of the study was carried out in July-November 2019.

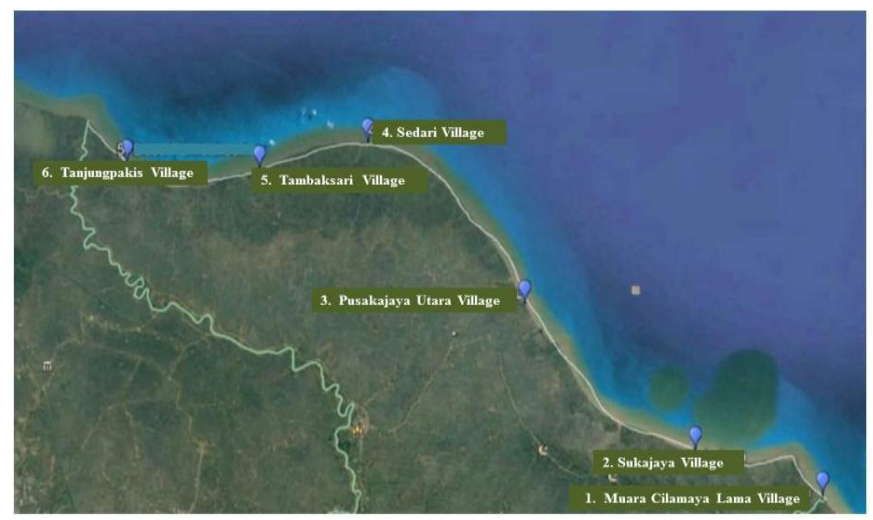

Fig. 1 Observation points along $\pm 75 \mathrm{~km}$ of the Karawang coastline (Source: Google Earth, 2019)

\section{B. Data Collection}

There are 2 types of data used, namely primary and secondary data [20]. Primary data is data collection directly to the research location by measuring hydro-oceanographic parameters such as depth and wave height around the coast which are needed for shoreline and wave modeling, as well as taking topographic data and images around the coast to see abrasion and sedimentation conditions, also conducting interviews with some local communities [21] [27]. This primary data collection is also used as data verification material and is also a Ground Check Point (GCP). While secondary data is a map of the coastal area of Karawang Regency, topographic data, bathymetry, waves, currents, tidal and wind data, and other supporting data [5].

While the equipment and materials for field surveys are to see the condition of the north coast of Karawang Regency and materials for processing satellite data, as shown in Table 1 and Table 2.

Table 1 Survey Equipment

\begin{tabular}{|c|c|c|}
\hline No. & Tools and Materials & Tool Specifications \\
\hline 1. & GPS Handheld & Garmin \\
\hline 2. & Waterpass & Topcon \\
\hline 3. & Tripod & - \\
\hline 4. & Ruler & - \\
\hline 5. & Camera & - \\
\hline 6. & Palm Tidal & - \\
\hline 7. & Roll Meter & Ms. Office \\
\hline 8. & Software Ms. Excel \& Word & CEDAS 2.01 \\
\hline 9. & Software & $\begin{array}{c}\text { Lakes Environmental } \\
\text { V.8.0.2 }\end{array}$ \\
\hline 10. & Software WRPLOT \\
\hline
\end{tabular}

Table 2 Research Materials

\begin{tabular}{|c|c|c|}
\hline No. & Tools and Materials & Material Source \\
\hline 1. & Bathymetry Map & GEBCO \\
\hline 2. & Tidal Data & BIG \\
\hline 3. & 10 Years Wind Data & ECMWF \\
\hline 4. & Coastline Data & Google Earth \\
\hline 5. & Field Information & Field Situation \\
\hline
\end{tabular}

How the data collection up to the determination of the selected coastal structure design is shown in Fig. 2.

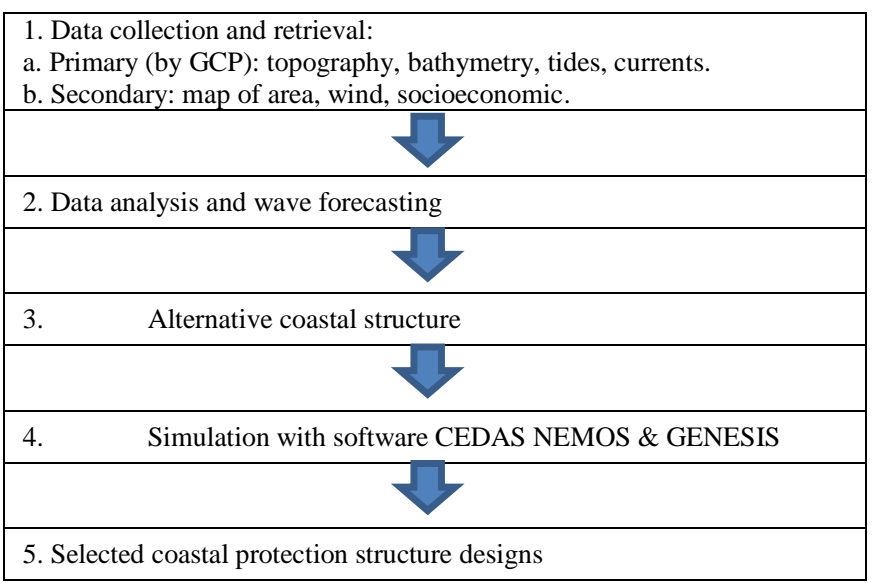

Fig. 2 Stages of data collection 


\section{Data Analysis}

Protection of coastal area by using coastal protection structures requires an appropriate and effective design in order to obtain optimal use [18]. Important parameters in the design and planning of a coastal protection structure such as wave height and others are used for detailed design, so that proper understanding and application will greatly support the achievement of an optimal design, both technically and economically [9]. The parameters used in the calculation of the detailed design, can be calculated and the calculation of each type of coastal protection structures is different [27].

The parameter for determining the design wave height is calculated using the graph of the intersection between the breaking waves calculated using the CEDAS (Coastal Engineering Design \& Analysis System) NEMOS (Nearshore Evolution Modeling System) program and GENESIS (Generalized Model for Simulating Shoreline Change). The first breakwater layout planning is determined where the location of the coastal protection structure should be, by using a graph of the calculation results of simple refraction waves the results of calculations using the program CEDAS [6].

According to [27], based on the calculation of the breaking wave height, it is known that the distance of the breaker line from the beach (Ybr), the location of the breakwater $\left(\mathrm{Y}_{\mathrm{B}}\right)$ is at $\mathrm{Y}_{\mathrm{B}}<\mathrm{Y}$ br. In order to form salient, so $Y_{B}=0,5 \mathrm{x} Y \mathrm{br}$. After the location of the breakwater is known, then the length of the breakwater is determined, which can be determined using the number Iribaren (I) that is:

$$
I=e^{\left(1.72-0.41 \frac{L_{B}}{Y_{B}}\right)}
$$

knowing that $\mathrm{Y}_{\mathrm{B}}$ can be calculated as $\mathrm{L}_{\mathrm{B}}$. In order to form salient then the length of the breakwater is:

$$
11.14 \leq \frac{L_{B}}{Y_{B}} \leq 1.965
$$

In terms of determining the distance between breakwaters, it is determined by the Suh and Dalrymple method [6].

\section{RESULT AND DISCUSSION}

\section{A. Geography, Topography and Bathymetry}

The area of Karawang Regency is geographically located between 1070 02'-1070 40' east longitude and 50 56'60 34' south latitude, including a relatively lowland area, having an altitude variation of 0-1,279 meters above sea level. The relatively low elevation is located in the northern part of several sub-districts [11]. So Karawang Regency is a lowland area with a small portion of highlands, especially in the south. The Karawang coast is a residential area and a fishery productive area (fish ponds) as a livelihood for the residents of the area [16].

Then the topographic data used is based on the National
DEM (Digital Elevation Model) data from the Geospatial Information Agency (Fig. 3). The National DEM is built from several data sources including IFSAR data (5m resolution), TERRASAR-X (5m resolution) and ALOS PALSAR $(11.25 \mathrm{~m}$ resolution), by adding the stereo-plotting Masspoint data. The spatial resolution of National DEM is 0.27- arcsecond, using the EGM2008 vertical datum.

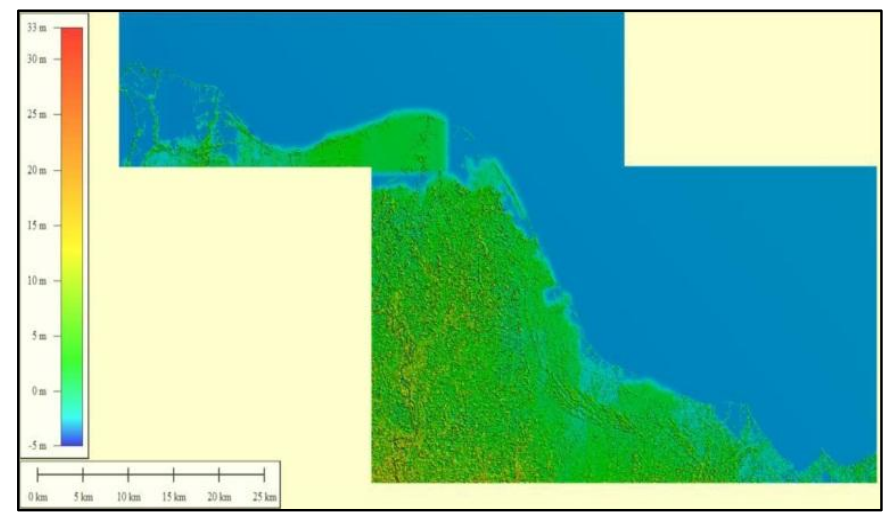

Fig. 3 National DEM data at the research site

Then the tidal data is obtained secondary from the Geospatial Information Agency (GIA) which is presented on the official website, namely http://tides.big.go.id/pasut/ (Fig. 4), then a ground check is carried out in the field at the coordinates as shown in Table 3.

Table 3 Coordinate Points Of Tidal Data Collection Gia

\begin{tabular}{|c|c|c|c|}
\hline Station & Easting & Northing & Information \\
\hline BIG Tidal & 107.26025 & -5.95256 & $\begin{array}{c}\text { Beach Area, Research } \\
\text { location Karawang }\end{array}$ \\
\hline
\end{tabular}

From the GIA data obtained above, after processing the tides using the Least Square method, the results of the analysis show that the coastal waters of Karawang have a single daily tidal type. In this type in one particular day a high tide occurs immediately after a low wave [21]. A typical tidal period is 12 hours 24 minutes. The tidal value based on the analysis using the Least Square method is 1.22 meters.

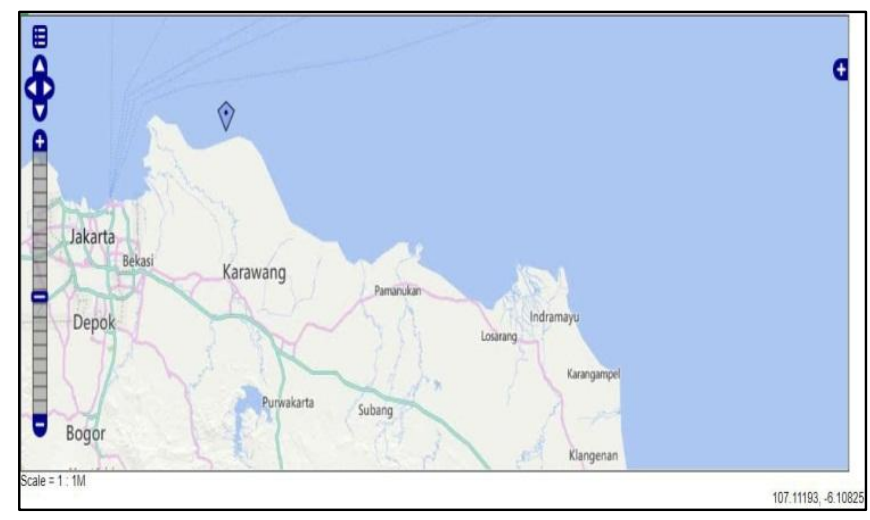

Fig. 4 Tidal data

The tidal data from the processing is then calibrated with field observation data as shown in Fig. 5. It can be 
concluded that the observations have data that are not much different from the data from the secondary data processing, namely from the Geospatial Information Agency (GIA). It was found that the tidal level was 1.22 meters.

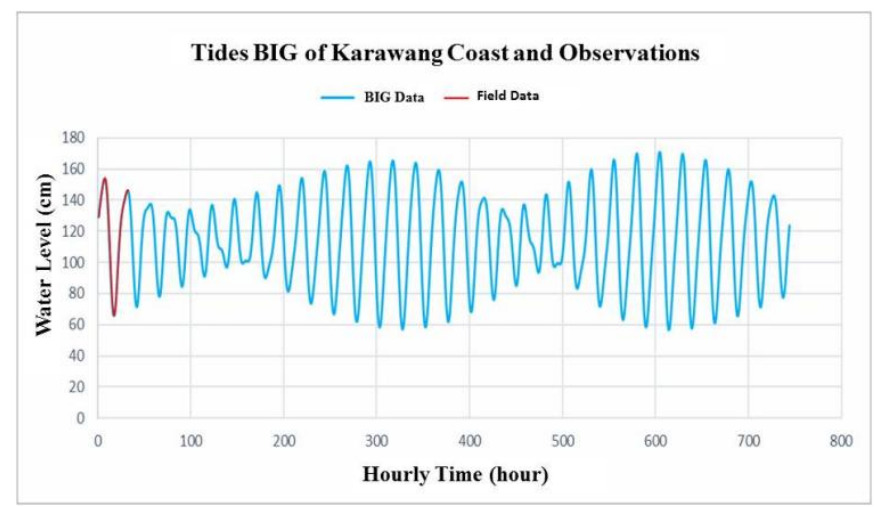

Fig. 5 GIA tide chart and observations.

Current velocity data is based on the results of studies that have been carried out previously, data obtained from current velocity in 3 main locations, namely Cibuaya District, Cilebar District and Cilamaya Kulon District, as shown in Table 4.

Table 4 Current Speed Data

\begin{tabular}{|c|c|}
\hline District & Average Current $(\mathrm{m} / \mathrm{dt})$ \\
\hline Cibuaya & 0.57 \\
\hline Cilebar & 0.42 \\
\hline Cimalaya Kulon & 0.40 \\
\hline
\end{tabular}

Wave data obtained by forecasting/predicting waves, which is done by processing wind data. Prediction of waves that are calculated based on past meteorological conditions or called hindcasting, waves in the sea in a waters generated by the wind, then propagate towards the coast and break along with the shallowing of the waters near the coast [14]. The results of wave forecasting are significant wave height and period for each wind data. To get the planned wave, wave forecasting is carried out based on long-term wind data. The method applied follows the method in the Shore Protection Manual (SPM). Wind data is used as input data for calculating wave heights that occur at the study site. The wind data used is wind data from ECMWF (European Center for MediumRange Weather Forecasts). In this study, wind data is used with a time period of 10 years (2006-2015) which is described in windroses.

Based on 10-year wind data starting from 2006 to 2015 the direction and speed of the wind dominance at the research location are from the East by $27 \%$ and from the Southeast by $20 \%$. The average wind speed at the research site is $4.8 \mathrm{~m} / \mathrm{s}$, where the greatest winds occur from the east and southeast. Of the total windrose, the dominant wind blows from the east throughout the year. Then followed from the west, northeast, and north which occurs in the west season, namely December to March. This wind data is used as data for wave generation in the hindcasting method. Where the waves in the sea which are considered the result of surface wind friction, can generate waves to the research location [9].

In detail, the wave height in the study area is described based on wind data at the study site (2006-2015) into a waverose diagram for Karawang and its surroundings (Fig. 6).

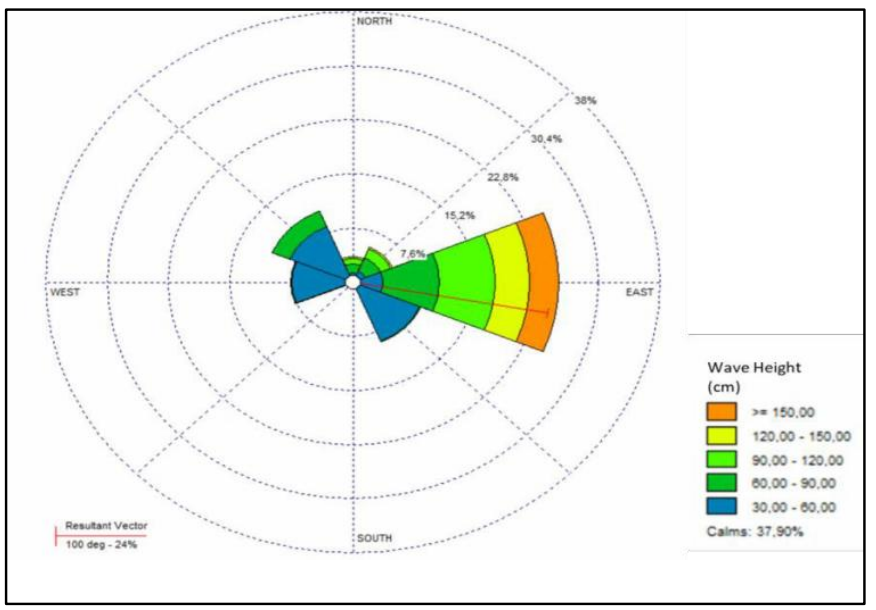

Fig. 6 Waverose wave height of Karawang waters (2006-2015)

Based on 10-year wave data starting from 2006 to 2015 the direction and height of the dominant wave at the research location were 25\% from the East and 10\% from the Northwest. The wave height at the research location ranged on average $0.98 \mathrm{~m}$, where the largest wave occurrences were from the East and Northwest. This wave data will be used as data for wave generation in the coastline simulation process using the GENESIS method. Before processing the data, the wave data obtained is plotted on a waverose to see the wave distribution every month in the form of a waverose.

Based on the waverose for 10 years, the wave dominance in the study location from the east was obtained with a data range between $30 \mathrm{~cm}$ to more than $150 \mathrm{~cm}$ for wave height. The waverose data is presented in the distribution to see the value of the percentage of wave dominance due to wind at the research location [14].

\section{B. Existing Shoreline Change Simulation}

In general, coast area needs protection so that it is not destroyed by sea waves. Protection can be done with a soft solution or a hard solution. Soft solutions (non-structure) can be in the form of planting mangrove trees, maintaining coral reefs, sand dunes on the beach, filling sand on the beach (sand nourishment). The hard solution (structure) method of handling is by making coastal protective structures, such as seawalls, groynes, jetties or breakwaters [12], as used in this study. Existing modeling is carried out to see the initial results of the GENESIS process which is then verified with Satellite Imagery data from Google Earth as a data calibration stage in the coastline model at the research location. In this simulation, the coastline model is divided, whether groyne, jetty, revetment, seawall, or breakwater. This is because the research 
location is very long, which is $\pm 75 \mathrm{~km}$, so it is divided into two model areas [21] [27]. The first model area is for the coastal areas of Muara Cilamaya Lama Village, Sukajaya Village and Pusakajaya Utara Village (Fig. 7). The second model area is for the coastal areas of Sedari Village, Tambaksari Village and Tanjungpakis Village (Fig. 8).

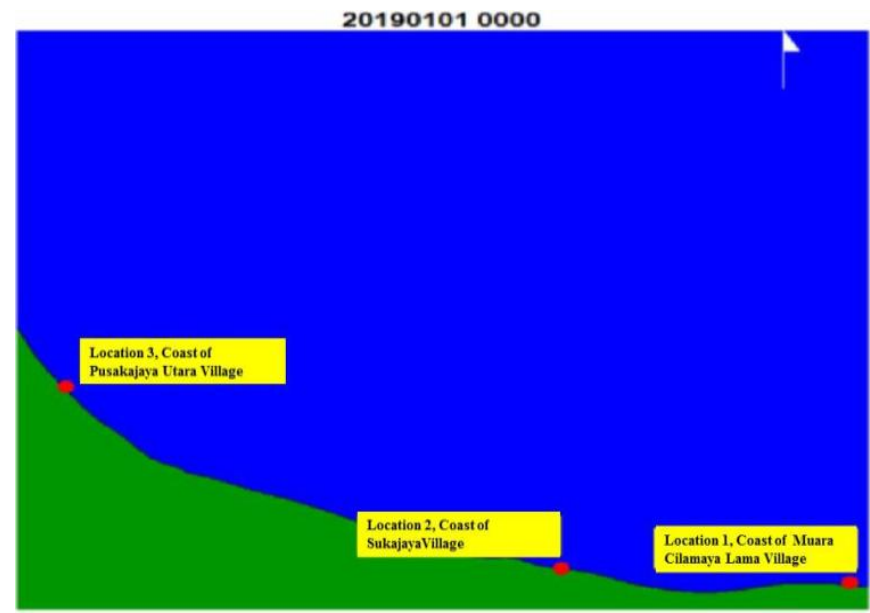

Fig. The coastline of the first model area

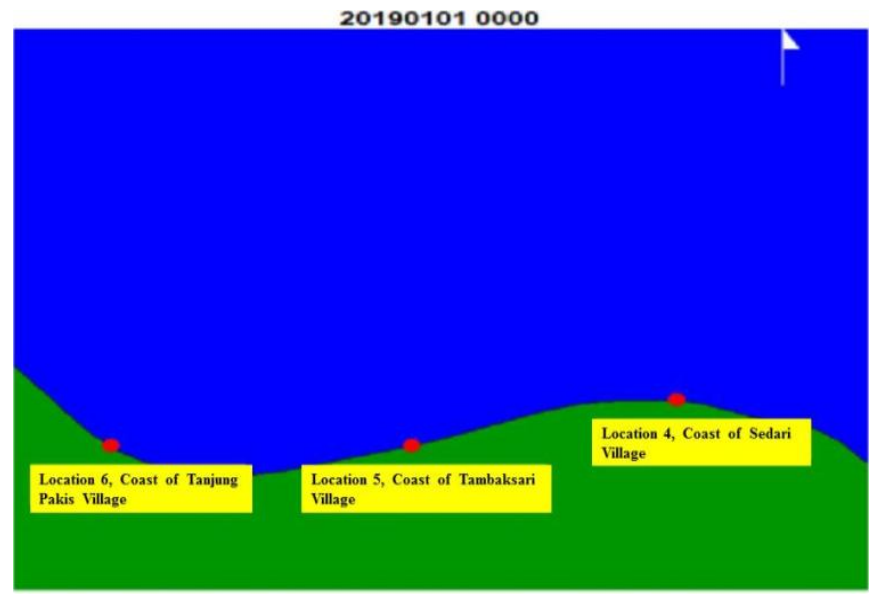

Fig. 8 The coastline of the second model area

The direction of the waves on the coast of Karawang is from the Northeast and the East hits the research location in 6 coastal areas (Fig. 1). At the research location at 6 coastal points of Karawang, the coast of Karawang Regency, the direction of waves from the Northeast and from the East, is indeed not perpendicular, meaning that in some locations erosion and deposition (formation of new sediment) can occur.

The results from field observations and result from modelling using CEDAS NEMOS and GENESIS, some problems can be elaborated and can be used for subsequent predictions, so that the problems in this research as a whole can be solved. For more details, that the results of the GENESIS modeling are then zoomed at each study point to be calibrated with satellite imagery data, then the results from this medelling system can be seen at first model area at Fig. 9, Fig. 10, Fig. 11 and second model area at Fig. 12, Fig. 13, Fig. 14.

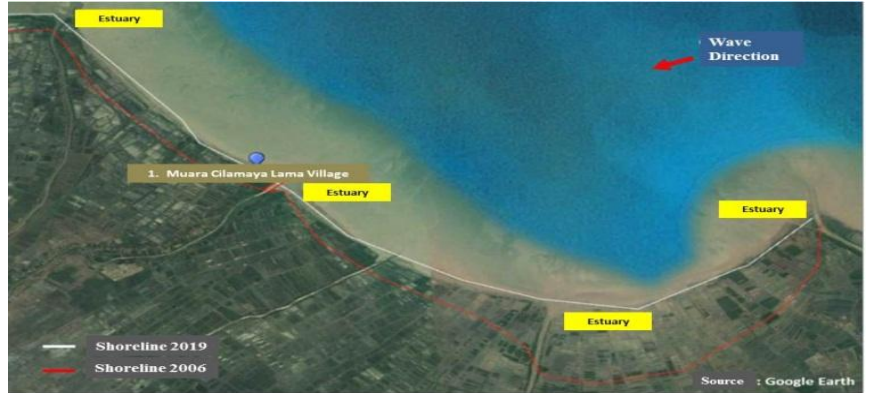

Fig. 9 Location beach-1 in Muara Cilamaya Lama Village

Coast of Muara Cilamaya Lama Village, based on the dominant direction of waves that occur from the Northeast and East, the condition of the coastline according to initial observations through satellite imagery from Google Earth, significant sedimentation is obtained. So, at this location, a coastal protection structure in the form of a jetty [28] was chosen which was built at the mouth of the river or estuary, as shown in yellow colour of Fig. 9 .

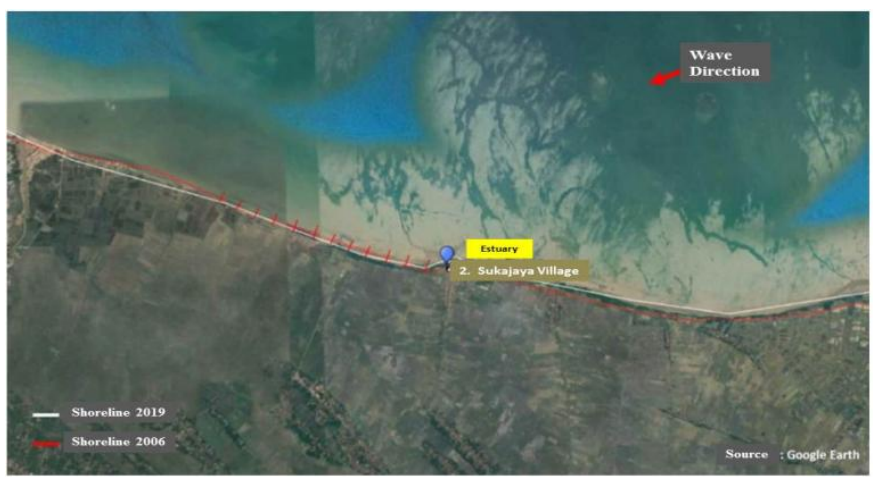

Fig. 10 Location beach-2 in Sukajaya Village

Then for the coast of Sukajaya Village (Fig.10), based on the dominant direction of waves that occur from the Northeast and East, the condition of the coastline is according to initial observations through satellite imagery from Google Earth and the direction of the waves is towards the beach but not perpendicular so that a suitable coastal protection structure is a groyne [28].

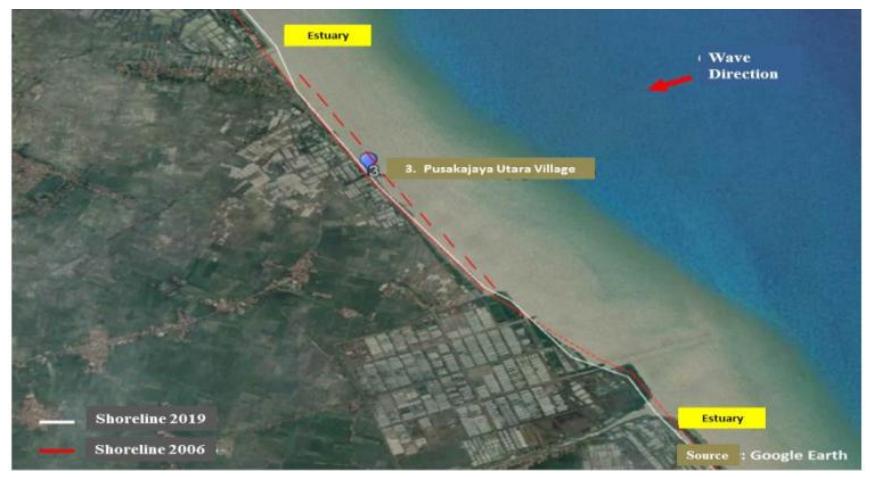

Figure 11 Location beach-3 in Pusakajaya Utara Village

As for the coast of Pusakajaya Utara Village (Fig. 11), based on the dominant direction of waves that occur from the 
Northeast and East, the shoreline conditions are according to initial observations through satellite imagery from Google Earth and the direction of the waves is towards the beach and perpendicular so that a suitable protection structure is a breakwater [28].

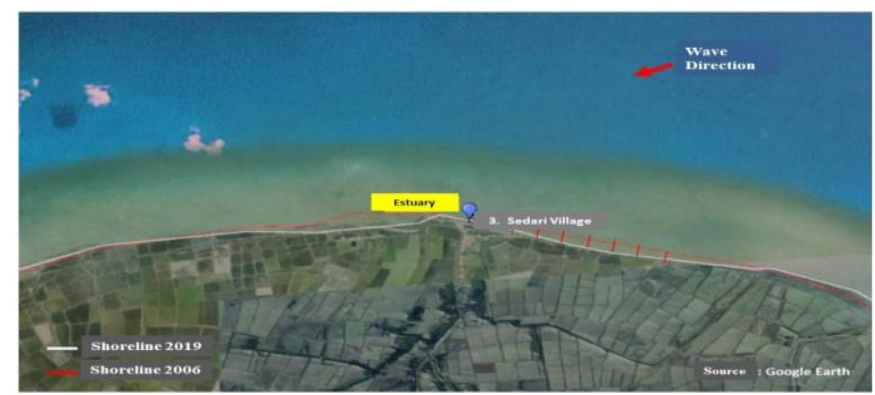

Fig. 12 Location beach-4 in Sedari Village

Sedari Village coast (Fig. 12), based on the dominant direction of waves that occur from the Northeast and East, the condition of the coastline is according to initial observations through satellite imagery from google earth and the direction of the waves is towards the beach but not perpendicular so that a suitable protection structure is a groyne [28].

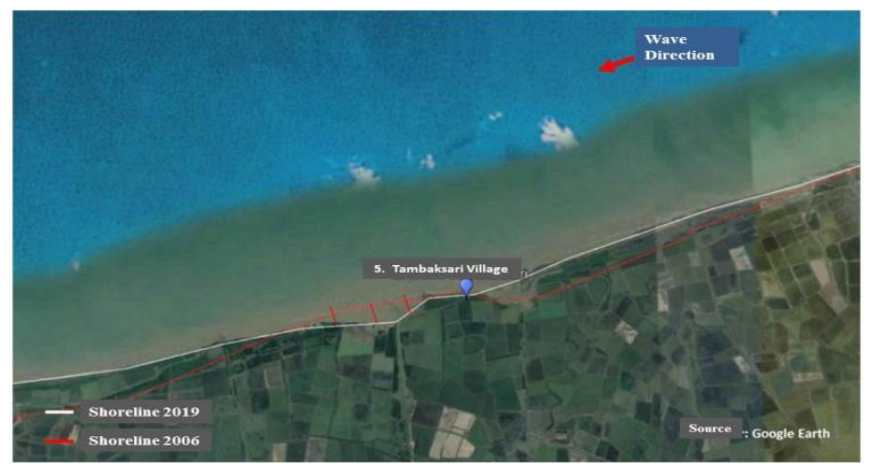

Fig. 13 Location beach-5 in Tambaksari Village

Tambaksari Village coast (Fig. 13), based on the dominant direction of waves that occur from the Northeast and East, the condition of the coastline is according to initial observations through satellite imagery from Google Earth and the direction of the waves is towards the beach but not perpendicular so that the suitable coastal protection structure is a groyne [28].

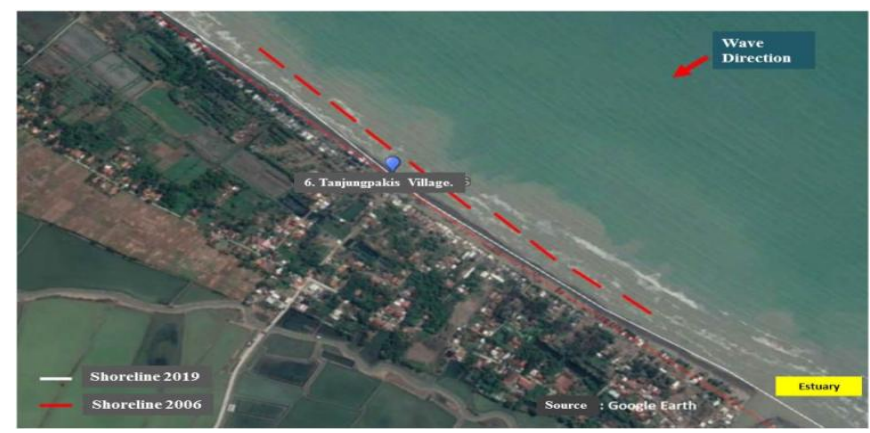

Fig. 14 Location beach-6 in Tanjungpakis Village
Tanjungpakis Village coast (Fig. 14), based on the dominant direction of waves that occur from the Northeast and East, the condition of the coastline is according to initial observations through satellite imagery from google earth and the direction of the waves is towards the beach and perpendicular so that the suitable coastal protection structure is the breakwater [28].

\section{Simulation of Shoreline Change After Handling}

After modeling the existing shoreline, then modeling the shoreline at each location with the handling of coastal structures is carried out. The following is one of the results of treatment using a breakwater (Fig. 15) and groynes (Fig. 16). The red line in the graph showing the initials, is the existing shoreline. Then the blue line is the final line, which is the predicted coastline for the next 10 years after treatment using breakwaters (Fig. 15) and groynes (Fig. 16).

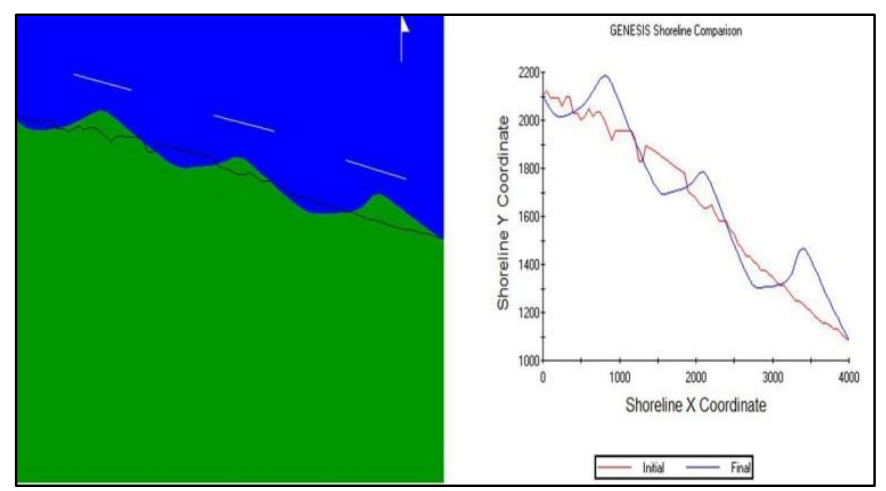

Fig. 15 Coastline model after treatment with breakwater

The resulting sediment transport volume of 306,000 $\mathrm{m} 3$ for 10 years of simulation with the dominant wave direction from the east based on the calculated wave height value is $1.47 \mathrm{~m}$ and the wave period is 5.4 seconds (Fig. 15).

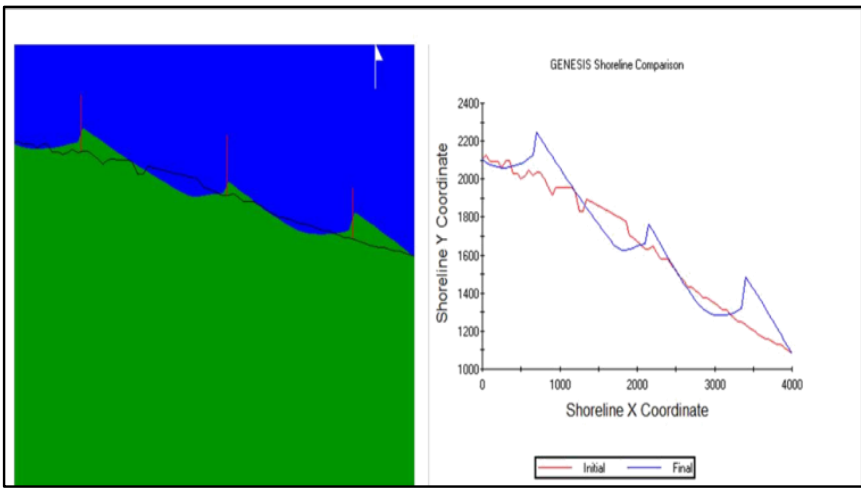

Fig. 16 Coastline model after treatment with groyne

The resulting sediment transport volume of 209,000 $\mathrm{m} 3$ for 10 years of simulation with the dominant wave direction from the east based on the calculated wave height value is $1.47 \mathrm{~m}$ and the wave period is 5.4 seconds (Fig. 16).

Then based on the results of the graph plot between breaking waves and refracted-diffraction waves, it is found 
that intersection is at depth of $6.5 \mathrm{~m}$ with wave height of 1.35 $\mathrm{m}$. So it can be concluded that breaking wave height towards the research location from the time the wave broke was at a depth of $6.5 \mathrm{~m}$ with a wave height of $1.35 \mathrm{~m}$ (Fig. 17).

By using a graph of the calculation results of simple refraction waves, the results of calculations using the CEDAS program are known to occur at a depth of 6.5 meters. Based on the calculation of the breaking wave height, it is known that the distance of the breaker line from the beach (Ybr) is \pm 100 $\mathrm{m}$. The location of the breakwater $\left(\mathrm{Y}_{B}\right)$ is at $\mathrm{Y}_{\mathrm{B}}<\mathrm{Ybr}$. In order to form a salient, then $Y_{B}=0.5 .100=50$, then the breakwater is planned to be built at a distance of 50 meters from the beach. Then in order to form a salient, the length of the breakwater is $L_{B}=1.9 \times 50=95 \mathrm{~m} \approx 100 \mathrm{~m}$, so the planned breakwater length is $100 \mathrm{~m}$. Furthermore, the distance between the breakwaters is determined by the Suh and Dalrymple method, and in order to form a salient, the distance between the breakwaters is $20 \mathrm{~m}$, with an illustration of the breakwater placement as shown in Fig. 18.

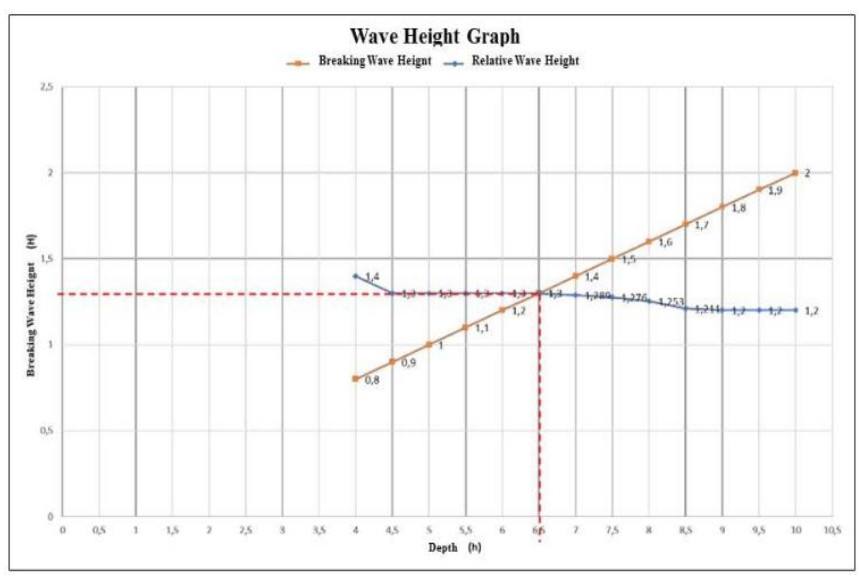

Fig. 17 Graph of breaking waves point at the research site

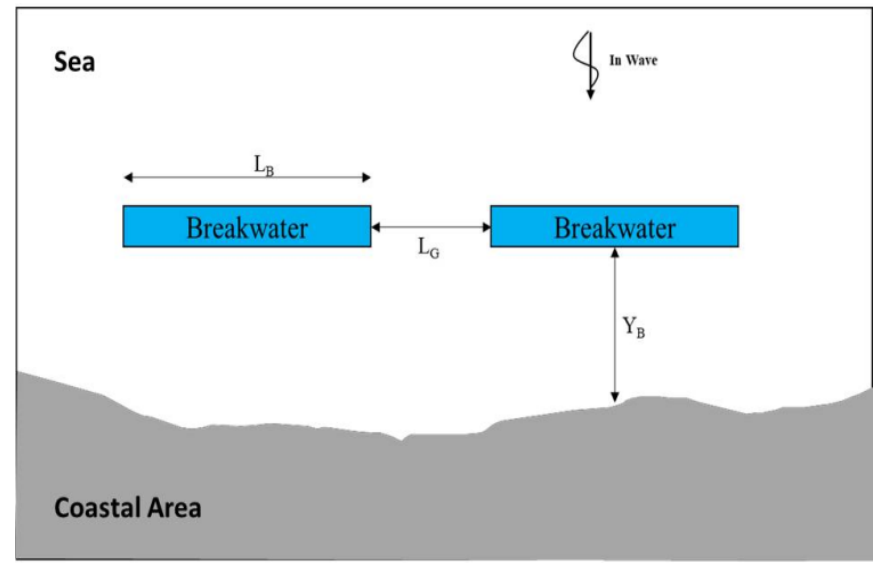

Fig. 18 Ilustration of breakwater placement layout

To facilitate implementation during construction at the research site, it was carried out in stages divided into three stages, namely the first stage, the second stage and the third stage.

\section{CONCLUSION AND RECOMMENDATION}

Based on the entire series of processes in this research, it can be concluded:

1. That the coast of Karawang requires coastal protection structures, because most of them have undergone physical changes, namely the coastline has retreated due to abrasion and sedimentation, so that it is very dangerous for the community if it is not handled seriously. The coastal protection structures development plans are: (1) alternative types of coastal protection structures that can be developed in Karawang are seawalls, revetments, groynes, jetties or breakwaters; (2) the types of coastal protection structures that are suitable for each research location village are breakwater (Pusaka Jaya Utara Village, Tanjungpakis Village) and groynes (Sukajaya Village, Sedari Village, Tambaksari Village), for the village of Muara Cilamaya Lama the jetty was chosen;

2. The results of the analysis related to how to determine the type and structure of the appropriate coastal protection for the coast of Karawang, can be done using the GENESIS application (software). This software is to predict shoreline changes in the future (10 years) if coastal protection structures are developed according to point 1 above, so that coastal protection system steps can be taken earlier. In addition, it can assist in determining the appropriate type of coastal protection structures, namely: (1) coastal protection structures that are suitable for the conditions of the Karawang coast are breakwaters and groynes, because they can reduce wave runoff, so as to protect the beach from wave attacks so that it does not occur abrasion; (2) the results of the analysis, it is obtained that the planning dimensions of coastal protection structures for breakwater are: structure height 6 meters, distance from the beach 50 meters; the length of the breakwater is 100 meters, the distance between the breakwaters is 20 meters, the function of the structure is to prevent abrasion;

Then based on the conclusions above, the recommendations submitted that coastal area of Karawang has undergone dangerous physical changes, the local government should immediately build a coastal protection structures in the form of a breakwater or groyne which is adjusted to its location, so that the damage to the coast does not get bigger and cause big losses. If a public sea port is built, the determination of the coastal protection structures for the public sea port area can use the results of this research.

\section{ACKNOWLEDGMENTS}

The authors would like to acknowledge the Regent of Karawang, the Head of the Karawang Fisheries Office and all his staff, as well as the people who live in coastal area of Karawang for their offering assistence during research implementation. Thanks are also conveyed to the Director of the Karawang Marine and Fisheries Polytechnic who has supported funding through 2019 State Budget of Indonesia. 


\section{REFERENCES}

[1] Aldin, M., Thaha, M. A., Hatta, M. P. (2019). Alternative Planning For Safety Building of Namrole Beach in South Buru RegencyMaluku. International Journal of Innovative Technology and Exploring Engineering (2019), 8 (4S)

[2] Fuad, M. A., Fajari, A. K., Hidayati, N. (2021). Pemodelan dan Analisis Perubahan Garis Pantai di Kabupaten Situbondo, Jawa Timur. Journal of Fisheries and Marine Research, Universitas Brawijaya, Malang, Vol 5 No.2 (2021) 335-349, DOI: 10.21776/Ub.Jfmr.2021.005.02.19

[3] Haryani, E. B. S., Soeprijadi, L., Pasaribu, R., Pattirane, C. P., Tanjung, A. (2020). Impact of Abration and Sedimentation to Change of Coastline in Coastal Area of Karawang Regency. Presented at The 4-th EMBRIO International Workshop, Current Advance in Tropical Marine Biodiversity and Fisheries, 10 September 2020, not published yet.

[4] Haryani, E. B. S., \& Fauzi, A. (2019). Bioeconomic analysis on coral fish in Raja Ampat Regency, West Papua Province. In IOP Conference Series: Earth and Environmental Science (Vol. 278, No. 1, p. 012032). IOP Publishing.

[5] Hasan, M. I. (2016). Main Materials of Research Methodology and Its Applications. Bogor: Ghalia Indonesia.

[6] Hariyadi. (2011). Analysis of Coastline Changes for 10 Years Using CEDAS (Coastal Engineering Design and Analysis System) in Teluk Awur Waters in the Scenario of Adding Coastal Protective Buildings. Semarang: Department of Marine Science, Faculty of Fisheries and Marine Sciences, Diponegoro University, Semarang, Marina Oceanography Bulletin October 2011.vol.1 82 - 94 (on-line), available at: http://ejournal.undip.ac.id/index.php /buloma/article/download/ 2986/2670.

[7] Karawang Regency Fisheries Office. (2020). Fisheries and Marine Potential and Production of Karawang.

[8] Kakisina, T. J. (2009). Groin Design to Overcome Erosion of the North Coastal Area of Baguala Bay, Ambon. Journal of Engineering Sciences and Science Technology Vol. 6 Number 1 April 2009.

[9] Komar, P. D., Moore, J. R. (2017). CRC Handbook of Coastal Processes and Erosion. DOI: 10.1201/9781351072908, Boca Raton: CRC Press.

[10] Kramadibrata, S. (2017). Port Planning. Bandung: ITB Publisher

[11] Local Government of Karawang Regency. (2021). Online availabel at: https://www.karawangkab.go.id. (24 October 2021).

[12] Masselink, G. (2021). Sandy Beach Morphodynamics. Journal of Coastal Research, (2021), 37(2). DOI: 10.2112/jcoastres-d-20a00008.1

[13] Marmoush, R. Y. \& Mulligan, R. P. (2020). A three-dimensional laboratory investigation of beach morphology change during a storm event. Geomorphology Journal: 363. DOI: 10.1016/j.geomorph.2020.107224.

[14] Marmoush, R. Y. \& Mulligan, R. P. (2021). Numerical modelling of alongshore variability in waves and wave-driven currents during the morphodynamic change of a laboratory beach. Coastal Engineering, (2021), 167. DOI: 10.1016/j.coastaleng.2021.103913

[15] Ministry of Transportation, Republic of Indonesia. (2015). Relocation of Cilamaya Port is Expected Not Far from Karawang (on-line), available on the News Website dated April 6, 2015: http://dephub.go.id/berita/ baca/pemindahan-lokasi-pelabuhancilamaya-diharapkan-tak-jauh-darikarawang/?cat=QmVyaXRhfHNIY3Rpb24tNjU $=$

[16] Pranoto, A. K., Haryani, E. B. S., \& Tanjung, A. (2019). The impact of coastal degradation on mangrove ecosystem in North Karawang coastal area. In IOP Conference Series: Earth and Environmental Science (Vol. 278, No. 1, p. 012061). IOP Publishing.

[17] Purba M. \& I. Jaya. (2004). Analysis of Coastline Change and Land Cover Between Way Penet and Way Sekampung, East Lampung Regency. Indonesian Journal of Aquatic and Fishery Sciences 11(2): 109-121.
[18] Ribas, F., Falques, A., Garnier, R. (2017). Nearshore Sand Bars on Western Mediterranean Beaches, in book of Atlas of Bedforms in the Western Mediterranean. DOI: 10.1007/978-3-319-33940-5_14

[19] Solihuddin, T., Prihantono, J., Mustikasari, J., Husrin, S. (2020). The dynamics of shoreline changes in the waters of Banten Bay and its surroundings. Journal of Marine Geology (2020), 18(2).

[20] Sugiyono. (2020). Qualitative Quantitative Research Methods and R \& D, 2nd Edition. Bandung: Alphabeta Publisher.

[21] Triatmodjo, B. (2018). Coastal Engineering. Yogyakarta: Beta Offset.

[22] Triatmodjo, B. (2016). Pelabuhan. Yogyakarta: Beta Offset.

[23] Taofiqurohman, A., Ismail, M. F. A. (2012). Spatial analysis of shoreline changes on the coast of Subang Regency, West Java. Journal of Tropical Fisheries and Marine Affairs, Sam Ratulangi University, Manado, Volume VIII-3, December 2012.

[24] Triwahyuni, A. (2009). Model of Changes in the East Coast of Tarakan, East Kalimantan [Thesis]. Bogor: Bogor Agricultural University.

[25] Wirekso, U. L. (2005). Planning of Coastal Protection Structure in Mundu-Balongan Area Using GENESIS Program Assistance) [Thesis]. Semarang: Diponegoro University, Institutional Repository (UNDIP-IR) (on-line) available at: https://123dok.com/document/ yroxopoy-planning-pengamanbalongan-using-diponegoro-university-institutionalrepository.html, (October 24, 2021, 12:30).

[26] Winarno, D. J. (2009). Analysis of Natural Boundary Conditions on Abrasion at Lampung Beach. Online availabel at: http://digilib.unila.ac.id/go.php?id=laptunilapp-gdl-res-2007dwijokowin-111 (27 June 2009).

[27] Yuwono, N. (2018). Coastal Engineering. Yogyakarta: Publishing Bureau for Civil Engineering Student Families, Faculty of Engineering, Gadjah Mada University.

[28] Yuwono, N. (2017). Basic of Coastal Structure Planning. Yogyakarta: Publishing Bureau for Civil Engineering Student Families, Faculty of Engineering, Gadjah Mada University. 